\title{
WYBORY 2015 ROKU W POLSCE - ANALIZA Z PERSPEKTYWY EWOLUCJI SYSTEMU PARTYJNEGO
}

\author{
THE ELECTIONS OF 2015 IN POLAND: \\ ANALYSIS FROM THE PERSPECTIVE OF EVOLUTION \\ OF THE PARTY SYSTEM
}

\author{
Dominik Sieklucki*
}

\begin{abstract}
- ABSTRAKT
Celem artykułu jest określenie znaczenia wyborów prezydenckich i parlamentarnych 2015 r. dla procesu ewolucji polskiego systemu partyjnego. Autor weryfikuje trzy hipotezy - pierwszą, według której wybory nie przyniosły zmian w strukturze systemu partyjnego, drugą - wybory zapoczątkowały nowy etap w tym procesie - i trzecią, wskazującą, że wybory przyniosły nowe zjawiska $\mathrm{w}$ procesie ewolucji, które w przypadku potwierdzenia się i ugruntowania w przyszłości mogą wprowadzić system partyjny w nowy etap. Autor stwierdza, że trzecia hipoteza w prawidłowy sposób określa znaczenie elekcji 2015 r. Analiza bazuje na metodologii nauk o polityce i prowadzona jest zarówno w wymiarze ilościowym, jak i jakościowym.
\end{abstract}

Słowa kluczowe: wybory, partie polityczne, system partyjny, rywalizacja polityczna, kampania wyborcza
The aim of the article is to ascertain the impact of 2015 presidential and parliamentary elections on the Polish party evolution process. Author verifies three hypotheses: first - elections have no influence on structure of the party system, second - elections are a new stage in evolution process, and third - elections of 2015 made some changes in the evolution of the party system, which, in case of consolidation and confirmation in subsequent elections, justifies their recognition as a transition phase. Author concludes that last hypothesis explains the impact of 2015 elections. Author analyses elections from quantitative and qualitative perspectives using methodology of political sciences.

Keywords: elections, political parties, party system, political rivalry, election campaign

\footnotetext{
* Uniwersytet Jagielloński w Krakowie, Wydział Studiów Międzynarodowych i Politycznych.
} 


\section{WSTĘP}

W 2015 r. odbyły się szóste wybory prezydenckie i ósme wybory parlamentarne w historii III Rzeczypospolitej, przynosząc szereg ważnych, interesujących i niekiedy nowych zjawisk w przebiegu i strukturze rywalizacji wyborczej. Niektóre z nich zostały poddane szczegółowym analizom (Kułakowska, Borowiec, Ścigaj, 2016; Brzezińska, Jarentowski, Matuszewski, 2016; Markowski, 2016). Zauważalny jest natomiast brak w polskiej literaturze całościowej analizy politologicznej o charakterze systemowym, umieszczającej elekcje 2015 r. w szerszej perspektywie procesu ewolucji polskiego systemu partyjnego. Konceptualizacja problemu badawczego prowadzi do sformułowania trzech pytań badawczych i towarzyszących im hipotez.

- pierwsze - czy wybory 2015 r. to nowy etap w procesie ewolucji polskiego systemu partyjnego? Hipoteza 1: wybory 2015 r. wyznaczają nowy etap $\mathrm{w}$ procesie ewolucji systemu partyjnego.

- drugie - czy wybory 2015 r. to kontynuacja stwierdzonych wcześniej cech polskiego systemu partyjnego? Hipoteza 2: wybory 2015 r. nie przynoszą zmian w systemie partyjnym, świadcząc o jego postępującej instytucjonalizacji.

- trzecie - czy wybory 2015 r. przyniosły zjawiska w procesie ewolucji systemu partyjnego, które w przypadku ugruntowania się i potwierdzenia w kolejnych elekcjach, uzasadniają uznanie ich za fazę przejścia w nowy etap. Hipoteza 3: wybory 2015 r. to in statu nascendi nowego etapu ewolucji polskiego systemu partyjnego.

Dla realizacji tak określonego problemu badawczego analizę podzieliłem na pięć części. Pierwsza zawiera podstawowe ustalenia metodologiczne. W drugiej przedstawiam proces ewolucji polskiego systemu partyjnego, ze szczególnym uwzględnieniem etapu, w jakim znajdował się przed wyborami 2015 r. W części trzeciej analizuję wybory prezydenckie z punktu widzenia ich wpływu na elekcję parlamentarną. Na część czwartą składa się analiza wyborów 2015 r. w perspektywach ilościowej i jakościowej, pozwalająca na weryfikację hipotez, a ostatnia zawiera podstawowe wnioski z prowadzonej analizy. 


\section{ZAŁOŻENIA METODOLOGICZNE}

Dla realizacji tak określonego problemu wykorzystałem cztery główne metody badawcze spośród stosowanych w naukach o polityce (Chmaj, Żmigrodzki, 1996). Punktem wyjścia była metoda empiryczna pozwalająca na zgromadzenie danych oraz informacji dotyczących podejmowanej problematyki, w tym w szczególności dotyczących przebiegu, wynik i struktury rywalizacji politycznej w wyborach 2015 r. Metoda, a właściwie metody ilościowe zostały wykorzystane w części, w której zajmuję się wyborami w tej właśnie perspektywie. W częściach dotyczących wpływu wyborów prezydenckich na parlamentarne oraz obejmujących jakościowy wymiar wyborów sięgnąłem do metod systemowej oraz jakościowej. Metoda systemowa pozwoliła na poszukiwanie korelacji między opisywanymi zjawiskami i poszukiwanie zależności miedzy parametrami opisującymi polski system partyjny. Natomiast metoda jakościowa została wykorzystana do oceny, interpretacji oraz wyjaśniania opisywanych zjawisk. Te dwie metody uzupełnione o wspominaną metodę ilościową zostały również wykorzystane w części analizującej proces ewolucji polskiego systemu partyjnego.

\section{EWOLUCJA POLSKIEGO SYSTEMU PARTYJNEGO}

Z metodologicznego punktu widzenia udzielenie odpowiedzi na sformułowane pytania badawcze wymaga przedstawienia w dużym skrócie procesu ewolucji polskiego systemu partyjnego. Pozwoli to, w połączeniu $\mathrm{z}$ analizami wyborów 2015 r. w perspektywach ilościowej i jakościowej, na wyodrębnienie jego zasadniczych cech charakterystycznych oraz na weryfikację lub falsyfikację postawionych we wstępie hipotez. Kwestia ta będzie przedmiotem rozważań w zakończeniu. Ze względu na objętość artykułu ograniczam się do podstawowych, syntetycznych uwag dotyczących ewolucji polskiego systemu partyjnego.

W literaturze przedmiotu przedstawiono wiele propozycji periodyzacji procesu jego kształtowania się (Antoszewski, 2012). Na potrzeby niniejszego artykułu przywołuję dwie koncepcje, które po pierwsze cechują się aktualnością, obejmując okres poprzedzający wybory 2015 r., oraz po drugie w przejrzysty sposób wskazują na podstawowe cechy charakteryzujące poszczególne etapy. Ponadto można je traktować jako komplementarne.

Według pierwszej propozycji sformułowanej przez Antoszewskiego (2012) w ewolucji systemu partyjnego Polski można wyodrębnić dwie fazy. Pierwsza 
obejmująca lata 1991-2001 została określona jako etap zabudowy sceny politycznej charakteryzujący się niestabilnością zachowań wyborców i często zmieniającą się ofertą wyborczą. Natomiast faza druga - postępującej stabilizacji - cechuje się zablokowaniem dostępu do parlamentu partiom nowym, względnie trwałym poparciem wyborczym dla partii parlamentarnych i wzrostem poparcia dla dwóch partii politycznych: Platformy Obywatelskiej i Prawa i Sprawiedliwości (Antoszewski, 2012). W świetle tej koncepcji pewnym problemem jest wkroczenie na arenę parlamentarną w 2011 r. Ruchu Palikota, który z poparciem 10,02 $\%$ głosujących uzyskał 40 mandatów poselskich. W sensie formalnym była to bowiem formacja nowa, ale należy zwrócić uwagę, że partia ta została założona przez polityka Platformy Obywatelskiej, wybranego z list tej partii do Sejmu, który w 2010 r. opuścił jej szeregi i założył własne ugrupowanie (Marzęcki, Stach, 2013). W tym znaczeniu Ruch Palikota nie był w pełni ugrupowaniem nowym, ponieważ parlamentarna geneza jego partii i aktywność polityczna lidera powalają na łączenie go z Platformą Obywatelską.

Według drugiej koncepcji autorstwa Jerzego Sielskiego (2006) polski system partyjny przeszedł następujące etapy ewolucji: w latach 1989-1990 funkcjonował system quasi - konsensualny, w latach 1990-1993 system rozbicia wielopartyjnego, w latach 1993-2005 system dwublokowy, a wybory 2005 r. wprowadziły go w system partii zwycięskiej. Należy nadmienić, że periodyzacja Sielskiego blisko koresponduje $\mathrm{z}$ innymi przedstawianymi w literaturze przedmiotu propozycjami, w których identycznie lub bardzo podobnie wyodrębnianym etapom nadawane są inne nazwy eksponujące określone cechy charakterystyczne (Sieklucki, 2010). W syntetycznym ujęciu przedstawiam je w tabeli 1 .

Tabela 1. Ewolucja polskiego systemu partyjnego

\begin{tabular}{|c|c|l|}
\hline Etapy & Okres & \multicolumn{1}{c|}{ Główne cechy } \\
\hline $\begin{array}{l}\text { System quasi- } \\
\text {-konsensualny }\end{array}$ & $1989-1990$ & $\begin{array}{l}\text { - rozkład bipolarnej struktury rywalizacji politycznej z wyborów 1989 r. } \\
\text { - dezintegracja obozu skupionego wokół PZPR } \\
\text { - wzorzec rywalizacji politycznej oparty o konsensus partii i ugrupowań } \\
\text { parlamentarnych } \\
\text { - rządy ponadpartyjne }\end{array}$ \\
\hline $\begin{array}{l}\text { System rozbicia } \\
\text { wielopartyjnego }\end{array}$ & $1990-1993$ & $\begin{array}{l}\text { - fragmentaryzacja systemu partyjnego } \\
\text { - dominacja partii małych } \\
\text { koalicyjne rządy mniejszościowe obejmujące od 4 do 7 partii } \\
\text { politycznych }\end{array}$ \\
\hline
\end{tabular}


Polskie Studia Politologiczne

\begin{tabular}{|c|c|c|}
\hline Etapy & Okres & Główne cechy \\
\hline $\begin{array}{l}\text { System } \\
\text { dwublokowy }\end{array}$ & 1993-2005 & $\begin{array}{l}\text { - bipolarna struktura rywalizacji politycznej między postpezetpeerowską } \\
\text { lewicą i postsolidarnościową prawicą i centroprawicą } \\
\text { - spadek liczby partii parlamentarnych } \\
\text { - koalicyjne rządy większościowe obejmujące od } 2 \text { do } 3 \text { ugrupowań poli- } \\
\text { tycznych, synkretyczne programowo, budowane w oparciu o kryterium } \\
\text { genezy partii politycznych }\end{array}$ \\
\hline $\begin{array}{l}\text { System partii } \\
\text { zwycięskiej }\end{array}$ & 2005-2011 & $\begin{array}{l}\text { - bipolarna struktura rywalizacji politycznej między partiami postsoli- } \\
\text { darnościowymi o profilu prawicowym i centroprawicowym } \\
\text { - stabilizacja liczby partii parlamentarnych } \\
\text { - koalicyjne rządy większościowe obejmujące od } 2 \text { do } 3 \text { partii poli- } \\
\text { tycznych, synkretyczne programowo, budowane w oparciu o względy } \\
\text { taktyczne }\end{array}$ \\
\hline
\end{tabular}

Źródło: na podstawie: J. Sielski (2006). Ewolucja polskiego systemu partyjnego. W: K. Kowalczyk, J. Sielski (red.), Partie i ugrupowania parlamentarne III Rzeczypospolitej, s. 11-23. Toruń: Dom Wydawniczy DUET; D. Sieklucki (2010). System partyjny Polski. W: B. Kosowska-Gąstoł (red.), Systemy partyjne państw Unii Europejskiej, s. 259-266. Kraków: Wydawnictwo Uniwersytetu Jagiellońskiego.

W odniesieniu do tabeli 1 należy zwrócić uwagę na dwie następujące kwestie. Po pierwsze wyodrębnienie czterech etapów w ewolucji polskiego systemu partyjnego zostało oparte o powiązane ze sobą kryteria jakościowe oraz ilościowe. Wśród nich mają kluczowe znaczenie: wzorzec rywalizacji politycznej, charakter rządów (a ściślej koalicji rządowych) oraz liczby partii na poziomie parlamentarnym wraz z poparciem dla poszczególnych ugrupowań, wskazującym, które z nich można uznać za bieguny rywalizacji, a które za partie małe, pełniące co najwyżej funkcje dopełniające w przetargach koalicyjnych i procesach decyzyjnych.

Po drugie przekształcenie, jakie dokonało się w polskim systemie partyjnym w 2005 r., wiązało się z następującymi procesami: znaczący spadek poparcia dla postpezetpeerowskiej lewicy, która straciła status bieguna rywalizacji politycznej (Sieklucki, 2009), spowodował przekształcenie się wzorca rywalizacji politycznej - główna oś konfliktu politycznego zaczęła przebiegać między dwiema partiami politycznymi o solidarnościowej genezie (PO i PiS), lokującymi się w grupie partii prawicowych (Antoszewski, 2008). Ponadto zgodnie z przedstawioną wcześniej periodyzacją procesu ewolucji polskiego systemu partyjnego znalazł się on w fazie stabilizacji charakteryzującej się dominacją dwóch ugrupowań politycznych, ograniczeniem pojawiania się partii nowych i względnie stabilną liczbą partii na poziomie parlamentarnym wynoszącą: sześć (po wyborach 2005 r.), cztery (po wyborach 2007 r.) i pięć (po wyborach 2011 r.). 
Należy również zwrócić uwagę, że wybory 2015 r. były normalnymi, kadencyjnymi wyborami, które nie odbywały się w jakiś szczególnie nadzwyczajnych okolicznościach i które przeprowadzono w oparciu o niezmienione od dłuższego czasu zasady i procedury. Posłowie wybierani są według tych samych reguł od wyborów 2005 r. (po zmianach jakie wprowadzono w ordynacji wyborczej z 12 kwietnia 2001 r. w Sejmie IV kadencji), a Kodeks wyborczy z 5 stycznia 2011 r. nie przyniósł w tym zakresie jakiś większych zmian jakościowych (Chmaj, Skrzydło, 2015).

\section{WYBORY PREZYDENCKIE 2015 R.}

Podjęcie analizy elekcji prezydenckiej jest spowodowane tym, że w Polsce - jak dowodzi Robert Alberski (2002) - obok w pewnym sensie podstawowej funkcji kreacyjnej wypełniają one również wiele innych funkcji, w tym wpływają na przebieg i wynik wyborów parlamentarnych (Bertoa, 2015), a niekiedy nawet inicjują zasadnicze zmiany w systemie partyjnym (Alberski, 2002). W 2015 r. wyraźny wpływ wyborów prezydenckich na parlamentarne w dużym stopniu był efektem zbieżności czasowej obu głosowań - wybory prezydenckie, a dokładnie ich druga tura odbyły 154 dni przed wyznaczoną datą wyborów do Sejmu i Senatu. Warto odnotować, że nie było to wprawdzie całkowite novum - tego typu sytuacja wystąpiła w 2005 r. i jak wskazuje Antoszewski (2007) miała wówczas znaczenie dla rywalizacji wyborczej oraz rezultatów wyborów, ale analogie nie są zbyt duże, ponieważ w 2005 r. pierwsze odbyły się wybory parlamentarne, a okres oddzielający obie elekcje wynosił wówczas tylko dwa tygodnie.

Początkowo, tj. w pierwszym kwartale 2015 r., można było spodziewać się, że wybory prezydenckie będą spełniać głównie funkcję prekampanii wyborczej przed wyborami parlamentarnymi. Wynikało to z notowań poszczególnych kandydatów w badaniach opinii publicznej. Mniej więcej do połowy marca na Bronisława Komorowskiego (PO) zamierzała głosować ponad połowa ankietowanych, a poparcie dla Andrzeja Dudy (PiS) nie przekraczało 20\%. Pozostali kandydaci uzyskiwali z reguły kilkuprocentowe poparcie (Preferencje w wyborach prezydenckich, CBOS, 2015). W takich okolicznościach wybory prezydenckie mogły służyć kreowaniu wizerunku partii politycznych przed jesiennymi wyborami. Od połowy marca poparcie dla urzędującego Prezydenta zaczęło wprawdzie spadać, ale jeszcze w kwietniu $66 \%$ ankietowanych wyrażało przekonanie, że to on wygra wybory prezydenckie, a o zwycięstwie Dudy było przekonanych tylko $12 \%$. Co 
więcej, tylko $42 \%$ deklarujących poparcie dla kandydata PiS twierdziło, że jest on w stanie wygrać wybory (Wybory prezydenckie: pewność głosowania, preferencje niezdecydowanych, i przewidywania wyniku wyborów, CBOS, 2015). W pewnym stopniu zaskakujące - w świetle badań opinii publicznej, choć niekoniecznie z punktu widzenia kampanii wyborczych prowadzonych przez obu kandydatów - zwycięstwo Dudy (Dudek, 2016; Piasecki, Michalak, 2016) wykazało bowiem zbieżność z notowaniami poszczególnych partii w badaniach opinii publicznej. Do kwietnia włącznie PO miało bowiem przewagę nad PiS (np. w marcu na PO zamierzało głosować $42 \%$ ankietowanych, a na PiS 29\%, w kwietniu odpowiednio $36 \%$ i 30\%), to już w maju odnotowano jednoprocentową przewage PiS, która utrzymała się od czerwca do dnia wyborów, oscylując na poziomie od 4\% do 11\% (Preferencje partyjne przed wyborami, CBOS, 2015). Tym samym zwycięstwo kandydata PiS pokazało, że wybory prezydenckie spełniają również funkcję mobilizacyjną.

Jej realizację można również zauważyć w odniesieniu do Pawła Kukiza. Niskie początkowo notowania znanego piosenkarza w sondażach, np. w marcu oddanie na niego głosu deklarowało $2 \%$ badanych (Preferencje $w$ wyborach prezydenckich, CBOS, 2015), mogły wskazywać, że będzie on jednym z kandydatów o niewielkim znaczeniu, ale jego ostateczny wynik (20,80\% głosów) pokazał, że w Sejmie może znaleźć się nowe ugrupowanie ze znaczącym poparciem. Charakterystyczny w tym kontekście jest początek dokumentu programowego Ruchu Kukiz'15, stwierdzający: „Jesteśmy głosem Narodu, który się obudził i chce odzyskać kontrolę nad swoim państwem” (Strategia zmiany, 2015).

Wynik Kukiza wskazywał, podobnie jak i kandydatki SLD, na zmiany w kształcie sceny politycznej, przy czym rezultat Magdaleny Ogórek (2,38\% głosów) - będący w dużym stopniu skumulowaniem licznych błędów nie tylko w prowadzonej kampanii (Sokołowski, 2016), ale również jej wizerunku, nieodpowiadającego partii o profilu lewicowym (Dudek, 2016) - tylko pogłębił kryzys lewicy, która przed wyborami parlamentarnym zmuszona została do podjęcia działań integracyjnych prowadzących do powołania koalicji Zjednoczona Lewica z udziałem pięciu ugrupowań SLD, TR, PPS, UP i Zielonych.

Podsumowując, wybory prezydenckie 2015 r. potwierdziły sformułowaną w odniesieniu do pierwszych czterech elekcji prezydenckich III RP tezę (Alberski, 2002) o znaczącym wpływie ich przebiegu, rywalizacji i wyników na późniejsze wybory parlamentarne. Wpływ ten był bardzo wyraźny - co w części wynikało z relatywnie krótkiego okresu oddzielającego obie elekcji - i przede wszystkim przejawiał się w zapowiedzi wejścia nowych ugrupowań do parlamentu, zwycię- 
stwa PiS, porażki PO i nieuzyskania reprezentacji przez lewicę. Wynik wyborów wywołał również konkretne skutki w obszarze działań marketingowych i strategii wyborczych poszczególnych ugrupowań.

\section{WYBORY PARLAMENTARNE 2015 R. - ANALIZA ILOŚCIOWA}

Analizując wyniki wyborów parlamentarnych z 25 października 2015 r., koncentruję się wyłącznie na Sejmie ze względu na jego pozycję w funkcjonującym w Polsce modelu bikameralizmu asymetrycznego. Dane porównawcze obejmują okres od elekcji 2005 r. - zgodnie z wcześniejszymi założeniami wtedy polski system partyjny wszedł w nową fazę ewolucji. Ponadto, jak wskazywałem od 2005 r. stosowany jest ten sam system wyborczy, co pozwala na prowadzenie analiz komparatystycznych. Z licznych parametrów, jakie mogą być stosowane do opisu systemu partyjnego (Rafałowski, 2017), ze względu na objętość artykułu ograniczam się do najistotniejszych z punktu widzenia wyborów $2015 \mathrm{r}$.

Tabela 2. Wyniki wyborów do Sejmu RP 2005-2015

\begin{tabular}{|l|c|c|c|c|c|c|c|c|}
\hline \multirow{2}{*}{ Komitet wyborczy } & \multicolumn{2}{|c|}{$\begin{array}{c}\text { Wybory } \\
\text { z 25.10.2015 }\end{array}$} & \multicolumn{2}{c|}{$\begin{array}{c}\text { Wybory } \\
\text { z 9.10.2011 }\end{array}$} & \multicolumn{2}{c|}{$\begin{array}{c}\text { Wybory } \\
\text { z 21.10.2007 }\end{array}$} & \multicolumn{2}{c|}{$\begin{array}{c}\text { Wybory } \\
\text { z 25.09.2005 }\end{array}$} \\
\cline { 2 - 10 } & $\begin{array}{c}\% \\
\text { głosów }\end{array}$ & $\begin{array}{c}\text { Liczba } \\
\text { mandatów }\end{array}$ & $\begin{array}{c}\% \\
\text { głosów }\end{array}$ & $\begin{array}{c}\text { Liczba } \\
\text { mandatów }\end{array}$ & $\begin{array}{c}\text { \% } \\
\text { głosów }\end{array}$ & $\begin{array}{c}\text { Liczba } \\
\text { mandatów }\end{array}$ & $\begin{array}{c}\% \\
\text { głosów }\end{array}$ & $\begin{array}{c}\text { Liczba } \\
\text { mandatów }\end{array}$ \\
\hline PiS & $\mathbf{3 7 , 5 8}$ & $\mathbf{2 3 5}$ & $\mathbf{2 9 , 8 9}$ & $\mathbf{1 5 7}$ & $\mathbf{3 2 , 1 1}$ & $\mathbf{1 6 6}$ & $\mathbf{2 6 , 9 9}$ & $\mathbf{1 5 5}$ \\
\hline PO & $\mathbf{2 4 , 0 9}$ & $\mathbf{1 3 8}$ & $\mathbf{3 9 , 1 8}$ & $\mathbf{2 0 7}$ & $\mathbf{4 1 , 5 1}$ & $\mathbf{2 0 9}$ & $\mathbf{2 4 , 1 4}$ & $\mathbf{1 3 3}$ \\
\hline KUKIZ'15 & $\mathbf{8 , 8 1}$ & $\mathbf{4 2}$ & - & - & - & - & - & - \\
\hline Nowoczesna & $\mathbf{7 , 6 0}$ & $\mathbf{2 8}$ & - & - & - & - & - & - \\
\hline PSL & $\mathbf{5 , 1 3}$ & $\mathbf{1 6}$ & $\mathbf{8 , 3 6}$ & $\mathbf{2 8}$ & $\mathbf{8 , 9 1}$ & $\mathbf{3 1}$ & $\mathbf{6 , 9 6}$ & $\mathbf{2 5}$ \\
\hline $\begin{array}{l}\text { Mniejszość } \\
\text { Niemiecka }\end{array}$ & $\mathbf{0 , 1 8}$ & $\mathbf{1}$ & $\mathbf{0 , 1 9}$ & $\mathbf{1}$ & $\mathbf{0 , 2 0}$ & $\mathbf{1}$ & $\mathbf{0 , 2 9}$ & $\mathbf{1}$ \\
\hline $\begin{array}{l}\text { Zjednoczona } \\
\text { Lewica/ SLD/LiD }\end{array}$ & 7,55 & 0 & $\mathbf{8 , 2 4}$ & $\mathbf{2 7}$ & $\mathbf{1 3 , 1 5}$ & $\mathbf{5 3}$ & $\mathbf{1 1 , 3 1}$ & $\mathbf{5 5}$ \\
\hline Ruch Palikota & - & - & $\mathbf{1 0 , 0 2}$ & $\mathbf{4 0}$ & - & - & - & - \\
\hline Samoobrona & 0,03 & - & 0,07 & - & 1,53 & - & $\mathbf{1 1 , 4 1}$ & $\mathbf{5 6}$ \\
\hline \multicolumn{1}{|c|}{ LPR } & - & - & - & - & 1,30 & - & $\mathbf{7 , 9 7}$ & $\mathbf{3 4}$ \\
\hline
\end{tabular}

Źródło: Obwieszczenia PKW o wynikach wyborów do Sejmu RP: Dz.U. 2015 poz. 1731, Dz.U. 2011 nr 218 poz. 1294; Dz.U. 2007 nr 198 poz. 1438, Dz.U. 2005 nr 195 poz. 1626. 
Dane zawarte w tabelach 2 i 3 wskazują, że pod względem kilku cech wybory 2015 r. nie przyniosły zmian o charakterze ilościowym - liczba partii parlamentarnych nie zmieniła się od poprzedniej elekcji, podobnie jak procent mandatów przejętych przez dwie najsilniejsze partie. Poparcie dla zwycięskiej partii politycznej w 2015 r. nie wykroczyło również poza pewne ramy z wcześniejszych wyborów - tzn. w analizowanym okresie nie było ani najwyższe (najwyższą liczbę głosów zdobyła PO w 2007 r.), ani najniższe (najmniejsze poparcie dla zwycięzcy wyborów miało miejsce w 2005 r.) i można z ilościowego punktu widzenia uznać je za dla typowe tego etapu.

Z perspektywy ilościowej należy jednak wyeksponować dwie ważne cechy wyborów 2015 r. Po pierwsze PiS zdobyło liczbę mandatów poselskich pozwalającą na samodzielne powołanie Rady Ministrów, przy czym jak wspominałem nie było to efektem wysokiego poparcia wyborczego. Świadczy o tym najwyższy w analizowanym okresie współczynnik rozmiaru nadreprezentacji najsilniejszej partii zamieszczony w tabeli 3, który osiągnął najwyższy poziom od wyborów 1991 r. (Antoszewski, 2012). Najwyższa jak dotąd liczba mandatów przejętych przez jedną partię polityczną to wypadkowa dwóch czynników - opisywanych wcześniej wyborów prezydenckich oraz konsekwencji stosowanego systemu wyborczego opartego na formule proporcjonalnej, metodzie d'Hondta i relatywnie dużych okręgach wyborczych, sprzyjających ugrupowaniom o wysokim poparciu. Zwraca się również uwagę (Dudek, 2016) na stosunkowo wysoki

Tabela 3. Wyniki wyborów do Sejmu RP 2005-2015 w ujęciu porównawczym

\begin{tabular}{|l|c|c|c|c|}
\hline & $\begin{array}{c}\text { Wybory } \\
\text { z 25.10.2015 }\end{array}$ & $\begin{array}{c}\text { Wybory } \\
\text { z 9.10.2011 }\end{array}$ & $\begin{array}{c}\text { Wybory } \\
\text { z 21.10.2007 }\end{array}$ & $\begin{array}{c}\text { Wybory } \\
\text { z 25.09.2005 }\end{array}$ \\
\hline Liczba partii na poziomie parlamentarnym & 5 & 5 & 4 & 6 \\
\hline $\begin{array}{l}\text { Rozmiar nadreprezentacji najsilniejszej } \\
\text { partii }\end{array}$ & 0,36 & 0,15 & 0,09 & 0,25 \\
\hline $\begin{array}{l}\text { Różnica między poparciem dla dwóch } \\
\text { najsilniejszych partii }\end{array}$ & 13,49 & 9,29 & 9,4 & 2,85 \\
\hline $\begin{array}{l}\text { \% mandatów zdobytych przez dwie } \\
\text { najsilniejsze partie }\end{array}$ & 81,09 & 79,13 & 81,52 & 62,61 \\
\hline Głosy „stracone” (w \%) & 16.62 & 4,11 & 4,12 & 10,93 \\
\hline
\end{tabular}

Źródło: A. Antoszewski. (2012). System polityczny RP. Warszawa: Wydawnictwo Naukowe PWN, s.158 i obliczenia własne. 
odsetek tzw. głosów straconych. Ponadto należy wskazać na relatywnie duży dystans dzielący dwie najsilniejsze partie, który w 2015 r. osiągnął 13,49 \%. W poprzednich elekcjach był on niższy, a tym samym w pewnym stopniu zmniejszał różnice w liczbie zdobytych mandatów na korzyść partii drugiej.

Po drugie wprawdzie w Sejmie VIII kadencji reprezentację uzyskała taka sama liczba partii politycznych co 4 lata wcześniej, ale nie były to te same partie. Można bowiem zauważyć, że od wyborów 2001 do elekcji 2011 r. na arenie parlamentarnej było obecnych od 4 do 6 partii politycznych, przy czym 4 stanowiły te same ugrupowania (PiS, PO, PSL i zmieniająca formuły organizacyjne postpezetpeerowska lewica). W Sejmach IV i V kadencji reprezentowane były ponadto Samoobrona i LPR, które jak się wydaje, trwale utraciły reprezentację wraz z wyborami 2007 r. W 2011 r. do wspominanej czwórki jednorazowo dołączył Ruch Palikota, który nie był w pełni nowym ugrupowaniem. Zasadnicze zmiany przyniosły w tym zakresie wybory 2015 r., w których reprezentację utraciła jedna parti ze wspominanej czwórki (lewica), a pojawiły się dwie zupełnie nowe. Ważne przy tym jest, że w wyborach 2011 partia nowa przejęła 8,7\% procent mandatów, a w 2015 r. nowe ugrupowania uzyskały już 15,2\%.

\section{WYBORY PARLAMENTARNE 2015 R. - ANALIZA JAKOŚCIOWA}

Wybory 2015 r. analizowane z tej perspektywy pozwalają na wyodrębnienie czterech nowych zjawisk, które wystąpiły w tej elekcji i które uznaję za istotne dla weryfikacji sformułowanych we wstępie hipotez badawczych. Po pierwsze reprezentację sejmową zdobyły dwa nowe ugrupowania polityczne, otrzymując łącznie 16,41\% głosów i zdobywając łącznie 70 mandatów poselskich. Pierwszym z nich jest Komitet Wyborczy Wyborców „Kukiz'15”, założony przez piosenkarza Pawła Kukiza po wyborach prezydenckich 2015 r. i zarejestrowany przez PKW 29 lipca. KWW „Kukiz'15” uzyskał poparcie $8,81 \%$ wyborców i zdobywając 42 mandaty poselskie stał się trzecią siłą polityczną w Sejmie. Warto zwrócić uwagę, że przybierające różne formy hasło „obalenia partiokracji”, podnoszone przez Kukiza w trakcie oraz po zakończeniu kampanii (Ruch Kukiza), spowodowało, że nie powołał w okresie wyborów partii politycznej, ograniczając się do założenia komitetu wyborczego, a po wyborach klubu poselskiego. Dlatego celowo użyłem wcześniej określenia ugrupowanie, ponieważ charakter organizacyjny działań Kukiza najbliższy jest kategorii ruchu społecznego (Heywood, 2008; Sobolewska-Myślik, 2004) i w taki sposób najczęściej jest określany (tj. jako 
ruch Kukiza). Problemów klasyfikacyjnych nie wywołuje natomiast drugie nowe ugrupowanie - partia polityczna „Nowoczesna Ryszarda Petru”, założona 31 maja 2015 r. i zarejestrowana niecałe dwa miesiące później (Kim jesteśmy?). Nowoczesna otrzymała 7,60\% głosów i zdobyła 28 mandatów poselskich.

Po drugie Sejm VIII kadencji jest pierwszym od rozpoczęcia procesu transformacji ustrojowej, w którym nie posiada reprezentacji postpezetpeerowska lewica. SLD po zwycięstwie wyborczym w koalicji z Unią Pracy w 2001 r. od wyborów 2005 r. odnotowywał stopniowy spadek poparcia wyborczego (Wojnicki, 2014), pomimo że w niektórych z nich startował w ramach koalicji wyborczych (LiD w 2007 i Zjednoczonej Lewicy w 2015 roku). Jest to cecha warta odnotowania ze względu na ciągłość reprezentacji w pierwszej izbie (dłuższym „stażem” parlamentarnym cechuje się tylko PSL), choć oczywiście od utraty statusu podstawowego bieguna rywalizacji politycznej w 2005 r. znaczenie SLD jako elementu systemu partyjnego było relatywnie niewielkie.

Po trzecie, jak wspominałem, PiS zdobyło bezwzględną większość mandatów w Sejmie, co pozwoliło tej partii na samodzielne powołanie rządu, bez konieczności stworzenia koalicji z inną partią reprezentowaną w Sejmie. Należy przy tym zwrócić uwagę, że rząd powołany po wyborach może być postrzegany jako niekoalicyjny (jednopartyjny) wyłącznie z formalnego punktu widzenia. PiS wystartowało w wyborach jako partia polityczna i nie podejmowało w Sejmie VIII kadencji rozmów koalicyjnych z inną partią polityczną, prowadzących do zawarcia umowy koalicyjnej. W praktyce charakter rządu jest jednak bardziej skomplikowany, ponieważ przed wyborami parlamentarnymi doszło do stworzenia faktycznej koalicji PiS z mniejszymi partiami politycznymi, tj. Polską Razem, Solidarną Polską i Prawicą Rzeczpospolitej (Dudek, 2016), ale porozumienie to nie przybrało postaci koalicji wyborczej, a politycy tych partii wystartowali $\mathrm{z}$ list Prawa i Sprawiedliwości (w tym m.in. liderzy pierwszych dwóch Jarosław Gowin i Zbigniew Ziobro). Zabieg ten wzbudził wątpliwości natury formalnej np. Roman Giertych dowodził, że PiS powinno zarejestrować się jako koalicja wyborcza (Niejasne zagrywki PiS z rejestracja komitetu wyborczego) i znacznie utrudnia też ocenę rządu kierowanego przez Beatę Szydło, który w praktyce również można uznać za quasi-koalicyjny.

Po czwarte w wyborach 2015 r. utrzymał się dotychczasowy wzorzec rywalizacji, ale w całościowo rozpatrywanej strukturze walki politycznej pojawiły się również elementy nowe. Nie powtarzając szczegółowej opublikowanej analizy tej problematyki (Sieklucki, 2016), należy zwrócić uwagę, że rywalizacja nadal miała charakter bipolarny, a jej główna oś przebiegała między PiS a Platformą 
Obywatelską. Ten główny kształt procesu rywalizacji „dopełniały” dwa bieguny: protestu (Kukiz'15 i KORWiN) oraz lewicowy (Zjednoczona Lewica i Partia Razem). Cechą charakterystyczną wyborów 2015 r. był spadek znaczenia lewicy, która nie zdobyła reprezentacji parlamentarnej, oraz wykształcenie się bieguna protestu, który uwzględniając wynik partii Janusza Korwina-Mikkego (4,76\%), łącznie uzyskał 13,57\% głosów. Umieszczenie obu ugrupowań w ramach jednego bieguna rywalizacji może wydawać się dyskusyjne, ale w moim przekonaniu łączy je zdecydowana krytyka polityk publicznych prowadzonych po $1989 \mathrm{oraz}$ elit i partii politycznych, a także prezentowanie programu daleko idących zmian ustrojowych w przypadku partii ruchu Kukiza w postaci niezbyt precyzyjnie zarysowanej koncepcji uchwalenia nowej konstytucji, a partii KORWiN - szczególna wizja ustroju oparta na nadrzędnej pozycji prezydenta i ograniczonej roli parlamentu (Sieklucki, 2016).

\section{WNIOSKI}

Udzielając odpowiedzi na postawione we wstępie pytania i odnosząc się do sformułowanych hipotez, należy stwierdzić, że wybory 2015 r. nie wprowadziły polskiego systemu partyjnego w nowy etap przynosząc wskazane nowości, nie pozwala jednak na podtrzymanie twierdzenia o tym, że znajduje się on w fazie stabilizacji. Dlatego za zweryfikowaną uważam hipotezę trzecią. Wspomniane nowości: wkroczenie na arenę parlamentarną dwóch nowych ugrupowań, powołanie jednopartyjnego rządu ( $\mathrm{z}$ uwzględnieniem sformułowanych wcześniej zastrzeżeń), brak reprezentacji lewicy przy jednoczesnym utrzymaniu się pewnych cech charakteryzujących polski system partyjny od wyborów $2005 \mathrm{r}$. - pozwalają zauważyć, że po okresie stabilizacji wszedł on w fazę niepewności i w pewnym znaczeniu dekoncentracji, wyznaczanej przekształcaniem się wzorca rywalizacji, dominacją jednej partii i obecnością partii nowych.

Uwzględniając również okres powyborczy można bowiem zarysować trzy możliwe scenariusze rozwoju polskiego systemu partyjnego. Pierwszy zakłada utrzymanie się dotychczasowego charakteru rywalizacji z ewentualnymi korektami polegającymi na uzupełnieniu go o biegun protestu i z możliwym brakiem reprezentacji parlamentarnej lewicy. Drugi zakłada dominację jednej dużej partii, z którą rywalizację będą podejmować mniejsze ugrupowania reprezentujące różne bieguny rywalizacji. Trzeci z kolei zakłada przekształcenie dotychczasowego wzorca rywalizacji w nowy, co będzie efektem słabnięcia 
dwóch najsilniejszych partii politycznych i wzrostu znaczenia nowych. Wyniki wyborcze Nowoczesnej i Ruchu Kukiza (ale też np. Partii Razem) pokazują bowiem, że występuje pewne społeczne zapotrzebowanie na organizacyjną i personalną nowość na polskiej scenie politycznej. Należy na koniec zauważyć, że przedstawione prognozy napotykają dwa istotne wyzwania. Po pierwsze kształt systemu partyjnego może zostać zdeterminowany przemianami systemu politycznego, zarówno całościowymi, jak i dotyczącymi pewnych jego elementów. Tytułem przykładu można wymienić zapowiedź Prezydenta przeprowadzenia referendum w sprawie konstytucji w 2018 r. czy możliwą zmianę ordynacji wyborczej, w której nowe rozwiązania mogą wpłynąć na kształt systemu partyjnego. Uwzględniając formułowane w poprzedniej dekadzie przez PiS propozycje wprowadzenia systemu mieszanego, można przywołać niedawno opublikowane wyniki badań Jarosława Flisa i Bartłomieja Michalaka (2017) pokazujące, że różne systemy generują w polskich warunkach różne wyniki wyborcze. Po drugie chwiejność zachowań części głosujących i przepływ elektoratu między partiami może wygenerować - niezależnie od poprzedniego czynnika - niespodziewany wynik wyborczy.

\section{Bibliografia:}

Alberski, R.(2002). Wybory prezydenckie w Polsce 1989-2000 i ich funkcje polityczne. W: A. Antoszewski (red.), Demokratyzacja w III Rzeczypospolitej (s. 117). Wrocław: Wydawnictwo Uniwersytetu Wrocławskiego.

Antoszewski, A. (2012). System polityczny RP. Warszawa: Wydawnictwo Naukowe PWN.

Antoszewski, A. (2008). Transformacja polskiego systemu partyjnego po 2005 roku. Athenaeum. Polskie Studia Politologiczne, 19, s. 14.

Antoszewski, A. (2007). Wybory parlamentarne i prezydenckie 2005 roku a instytucjonalizacja polskiego systemu partyjnego. W: T. Sasińska-Klas (red.), Media w wyborach. Kampanie wyborcze. Media w polityce (s. 48-49). Toruń: Wydawnictwo Adam Marszałek.

Bertoa, F.C. (2015). Polish Politics in 2015 All the Power to the Right. Pobrane z: http:// www.the-plot.org/2015/12/09/polish-politics-in-2015-all-the-power-to-the-right/.

Brzezińska, M.M., Jarentowski, M., Matuszewski, P. (red.). (2016). Wybory prezydenckie i parlamentarne w Polsce w 2015 roku: podobieństwa, różnice i wzajemne oddziaływania. Warszawa: Wydawnictwo Naukowe UKSW.

Chmaj, M., Skrzydło, W. (2015). System wyborczy w Rzeczypospolitej Polskiej. Warszawa: Wolters Kluwer. 
Chmaj, M., Żmigrodzki, M. (1996). Wprowadzenie do teorii polityki. Lublin: Wydawnictwo UMCS.

Dudek, A. (2016). Historia polityczna Polski 1989-2015. Kraków: Wydawnictwo Znak Horyzont.

Flis, J., Michalak, B. (2017). Mieszany system wyborczy - cztery warianty dla Polski. Athenaeum. Polskie Studia Politologiczne, 55, s. 76 - 84. DOI: 10.15804/ athena.2017.55.04.

Heywood, A. (2008). Politologia. Warszawa: Wydawnictwo Naukowe PWN.

Nowoczesna. (2017). Kim jesteśmy?. Pobrane z: https://nowoczesna.org/kim-jestesmy.

Kułakowska, M., Borowiec, P., Ścigaj, P. (red.). (2016). Oblicza kampanii wyborczych 2015. Kraków: Wydawnictwo Uniwersytetu Jagiellońskiego.

Markowski, R. (2016). The Polish Parlamentary Election of 2015: A Free and Fair Election That Results in Unfair Political Consequences. West European Politics, 39:6, s.1311-1322. DOI: 10.1080/01402382.2016.1177305.

Marzęcki, R., Stach, Ł. (2013). Dlaczego Palikot? Młodzi wyborcy Ruchu Palikota: przypadkowy czy „twardy” elektorat nowej sity na polskiej scenie politycznej. Warszawa: Dom Wydawniczy ELIPSA.

Niejasne zagrywki PiS z rejestracja komitetu wyborczego. Pobrane z: http://www.newsweek.pl/polska/pis-kaczynski-ziobro-gowin,artykuly,370184,1.html.

Obwieszczenia PKW o wynikach wyborów do Sejmu RP: Dz.U. 2015 poz. 1731, Dz.U. 2011 nr 218 poz. 1294; Dz.U. 2007 nr 198 poz. 1438, Dz.U. 2005 nr 195 poz. 1626.

Obwieszczenia PKW o wynikach wyborów prezydenckich: Dz.U. 1990 nr 83 poz. 483, Dz.U. 1995 nr 126 poz. 604, Dz.U. 2000 nr 85 poz. 952, Dz.U. 2005 nr 200 poz. 1647, Dz.U. 2010 nr 113 poz. 746, Dz.U. 2015 poz. 650

Piasecki, A., Michalak, R. (2016). Polska 1945-2015. Historia polityczna. PWN: Warszawa.

Preferencje partyjne przed wyborami. Komunikat z badań, nr 142. (2015). Warszawa: Centrum Badania Opinii Społecznej.

Preferencje partyjne w sierpniu. Komunikat z badań, nr 116. (2015). Warszawa: Centrum Badania Opinii Społecznej.

Preferencje $w$ wyborach prezydenckich. Komunikat z badań, nr 55. (2015). Warszawa: Centrum Badania Opinii Społecznej.

Rafałowski, W. (2017). Opisywanie i wyjaśnianie systemu partyjnego. Metody pomiaru. Warszawa: ASPRA-JR.

Sieklucki, D. (2010). System partyjny Polski. W: B. Kosowska-Gąstoł (red.), Systemy partyjne państw Unii Europejskiej (s. 259-266). Kraków: Wydawnictwo Uniwersytetu Jagiellońskiego.

Sieklucki, D. (2009). Wybory 2005 i 2007 roku a partie lewicy na polskiej scenie politycznej. Politeja, nr 2(12), s. 92-93

Sieklucki, D. (2016). Wzorce rywalizacji politycznej w kampaniach wyborczych $2015 \mathrm{r}$. W: M. Kułakowska, P. Borowiec, P. Ścigaj (red.), Oblicza kampanii wyborczych 2015 (s. 290 - 301). Kraków: Wydawnictwo Uniwersytetu Jagiellońskiego. 
Sielski, J. (2006). Ewolucja polskiego systemu partyjnego. W: K. Kowalczyk, J. Sielski (red.), Partie i ugrupowania parlamentarne III Rzeczypospolitej (s. 11-23). Toruń: Dom Wydawniczy DUET.

Sobolewska-Myślik, K. (2004). Partie i systemy partyjne na świecie. Warszawa: Wydawnictwo Naukowe PWN.

Sokołowski, J. (2016). Analiza działań marketingowych poszczególnych kandydatów w wyborach prezydenckich 2015 roku - Magdalena Ogórek. W: M. Kułakowska, P. Borowiec, P. Ścigaj (red.), Oblicza kampanii wyborczych 2015 (s. 117-118). Kraków: Wydawnictwo Uniwersytetu Jagiellońskiego.

Strategia zmiany. (2015). Pobrane z: http://ruchkukiza.pl/klub-poselski/strategia-zmiany/.

Wojnicki, J. (2014). Partie socjaldemokratyczne $w$ wybranych państwach Europy Środkowo-Wschodniej. Warszawa: Wydział Dziennikarstwa i Nauk Politycznych Uniwersytetu Warszawskiego.

Wybory prezydenckie: pewność głosowania, preferencje niezdecydowanych i przewidywania wyniku wyborów. Komunikat z badań, nr 60. (2015). Warszawa: Centrum Badania Opinii Społecznej.

Wybory 2011 do Sejmu i Senatu Rzeczypospolitej Polskiej. Wyniki wyborów. (2011) Pobrane z: http://wybory2011.pkw.gov.pl/wsw/pl/000000.html.

Wybory 2015 do Sejmu i Senatu Rzeczypospolitej Polskiej. Wyniki Sejm. (2015). Pobrane z: http://parlament2015.pkw.gov.pl/349_Wyniki_Sejm/0/0.

Wypowiedź Pawła Kukiza. (2017). Pobrane z: http://ruchkukiza.pl/. 